\title{
EMOTIONS IN MUSEUM EDUCATION. POTENTIAL FOR THE DEVELOPMENT OF A RELATIONSHIP TO CULTURAL AND HISTORICAL HERITAGE
}

LUCIE JAGOŠOVÁ

\section{ABSTRACT/ABSTRAKT:}

The educational potential of institutions which mediate cultural and historical heritage to their visitors is mostly being associated with transmission of knowledge and with education. It is so despite the fact that museums and other cultural and memory institutions are aware of the important role of psychological specifics of museum (culture, heritage protection) education and of the key role of emotions in the development of a relationship of visitors to cultural and historical heritage and in the effectiveness of education. The article pays attention to psychological aspects of education related both to the museum environment and to the visitors and their cultural competences, the role of experience, attention and regeneration of mental strength in cultural environment. It aims to emphasize the significance of additional benefits of visiting a cultural (museum) institution, such as relaxation and contemplation.

Emoce v muzejní edukaci. Potenciál pro rozvoj vztahu ke kulturně-historickému dědictví

Edukační potenciál institucí, které návštěvníkům zprostředkovávají kulturně-historické dědictví, bývá nejčastěji spojován s transmisí znalostí a pojmem vzdělávání, případně výchova. Je tomu tak i přesto, že si muzea a další kulturní a pamětové instituce uvědomují, jak významnou roli hrají v procesu učení také psychologická specifika muzejní (kulturní, památkové) edukace a jak klíčové při budování vztahu návštěvníka ke kulturněhistorickému dědictví i efektivitě učení jsou právě emoce. Článek věnuje pozornost psychologickým aspektům edukace vázaným jak na prostředí muzea, tak na osobnost návštěvníka a jeho kulturní kompetence, význam prožitku, pozornosti a obnovy duševních sil v kulturním prostředí. Směřuje ke zdůraznění významu dalších prrínosů z návštěvy kulturní (muzejní) instituce pro návštěvníka, jako je relaxace a kontemplace.

\section{KEYWORDS/KLÍČOVÁ SLOVA:}

emotions - museum education museum psychology - cultural and historical heritage - cultural education

emoce - muzejní edukace - muzejní psychologie - kulturně-historické dědictví - kulturní edukace

\section{Introduction}

From the aspect of audience, museums are mainly regarded as educational institutions, places where people go to learn and to broaden their intellectual horizons. Some museums are also profiled as destinations attractive for tourists. However, museums can offer much more - they can also be truly healing places where people go to relax, to recharge their batteries and to improve their mental and physical condition. ${ }^{1}$ Of crucial importance for deepening the relationship to historical heritage is the awareness of how the knowledge from pedagogical and psychological sciences and neurosciences can be used in museum presentation and education. Particularly important is the creation of an appropriate museum environment (museum architecture), the accent on respecting the knowledge of mental (rational and sensory cognition) and emotional development of man in the process of making exhibitions and permanent displays, preparation of educational programmes and projects (with knowledge of pedagogy, psychology, didactics etc.) and their evaluation (including the feedback from visitors) in professional education and personal/ social development of (future) museum pedagogues (pedeutology of museum pedagogy) and other staff in contact with visitors (including the training of staff).

Taking account of psychological principles in the effect to inside and outside of museums and other cultural and memory institutions goes far beyond the competences of museum pedagogy (and museum pedagogues, who in the Czech Republic are legislatively defined

$\overline{1 \text { WASMER ANDREWS, Linda. Museums as }}$ Healing Places: Musings on the mind-body health benefits of museums. Psychology Today [online]. 22. 12. 2010 [accessed 2019-10-19]. Available from www: <https://www.psychologytoday. com/blog/minding-the-body/201012/museumshealing-places $>$. 
as the so-called educators in culture; this professional profile encompasses educational work in various types of memory and cultural institutions). In the effort to develop the most complex and most efficient possible impact on the public, it enables to deepen the connections of museum education to other disciplines and areas (e.g. museum exhibition making, museum architecture, museum marketing and management etc.), having the potential for a wide and systematic interdisciplinary cooperation between museum professions. From among relevant museological subdisciplines we can mention the theories and researches in the area of museum psychology $y^{2}$ or the so-called neuromuseology. ${ }^{3}$ These problems have been adequately discussed and solved in the field of protection and conservation of monuments - in the so-called heritage education. In recent years, above all in foreign museums, the question of applying emotional education tools and using their didactic effects began to be pursued in addition to the remaining educational aspects. The debates, interlinking the current trend in museum education with the previous ones that accentuated knowledge, skills and attitudes, are thus focused on other aspects of educational activity and on the efficiency of a long-term impact of education on visitors.

Within the problem of education of the public towards a relationship to cultural and historical heritage, the text will focus on affective goals and tools and the potential of working with emotions, particularly in the museum environment.

2 SCHUSTER, Martin and Hildegard AMELNHAFFKE (eds.). Museums-Psychologie: Erleben im Kunstmuseum. Göttingen: Hogrefe Verlag, 2006.

3 E.g. FOLGA-JANUSZEWSKA, Dorota. Might the Museology be a part of Neurosciences? Museologica Brunensia, 2016, vol. 5, no. 1, pp. 5-14.

\section{Education towards a relationship to cultural and historical heritage}

Cultural (and historical) heritage in general represents a sum of cultural assets, works and values inherited from past generations, which are further subdivided into tangible and intangible cultural property. ${ }^{4}$ Cultural heritage constitutes the feeling of identity and continuity and supports therewith the respect to cultural diversity and human creativity and it is in public interest to preserve these elements for the future. The social value of cultural heritage, according to Hana Havlůjová, Petr Hudec and Martina Indrová, can be considered from the perspective of three strategies of its sustainability (sustainable development), leading not only to preservation but also to further increase in the value of the legacy of past generations in the form of heritage protection, education and marketing. The social value of cultural heritage is sustainable in the long term only when the effects of these three strategies are in mutual balance. Experiences from abroad have shown that, as regards the sustainability of the world's cultural diversity, a wellconsidered educational activity and its impact on the value orientation and attitudes of the public play an equally important role as the practical measures leading to physical and legislative

\footnotetext{
4 Material (tangible) cultural heritage encompasses monuments, including architecture, artefacts and archaeological relics, groups of buildings and sites, inclusive of archaeological sites, composed landscape of extraordinary historical, aesthetical or scientific significance. Immaterial (intangible) cultural heritage encompasses knowledge, skills as well as other artefacts and related cultural areas, which various communities or individuals regard as a part of their heritage. HAVLŮJOVÁ, Hana, Petr HUDEC and Martina INDROVÁ et al. Památky nás baví 1: Objevujeme kulturní dědictví s předškoláky a žáky 1. stupně základních škol. Metodika tvorby, realizace a hodnocení kvality edukačních programů $v$ oblasti péče o kulturní dèdictví pro primární vzdělávání [online]. Praha: Národní památkový ústav, 2015, pp. 15-16 [accessed 2019-12-13]. Available from www: <https://www.npu.cz/ publikace/pamatky-nas-bavi-1.pdf $>$.
}

protection of existing components of cultural heritage and promotion of emergence of new artefacts. ${ }^{5}$ In terms of heritage protection, the above-mentioned team of authors defines education in historical environment as a specific type of interpretation of cultural heritage, which exhibits common traits with education in museum institutions. The subject of interest are movable monuments ${ }^{6}$ (objects) in authentic context as well as immovable monuments and protected areas, with emphasis on their genius loci. From the pedagogical perspective we rather speak of heritage education $^{7}$ and the pedagogue engaged in heritage education or, in other words, education in historical environment, is usually referred to with a working term

5 HAVLU゚JOVÁ, Hana, Petr HUDEC and Martina INDROVÁ et al. Památky nás baví 1: Objevujeme kulturní dědictví s předškoláky a žáky 1. stupně základních škol. Metodika tvorby, realizace a hodnocení kvality edukačních programů v oblasti péče o kulturní dědictví pro primární vzdělávání [online]. Praha: Národní památkový ústav, 2015, pp. 15-16, 22-23 [accessed 2019-12-13]. Available from www: <https://www.npu.cz/publikace/ pamatky-nas-bavi-1.pdf >

6 The authors understand under the term monument in the broadest sense of the word an "object, which is protected from physical destruction for various reasons, e.g. the personal, cultural, historical or economic ones; it is an embodiment of memories or cultural memory; from the perspective of heritage protection we distinguish movable monuments, which are the most numerous components of heritage (e.g. paintings, sculptures, artisan's works, liturgical utensils, music works, but also technical monuments, architectonic elements of defunct buildings, archaeological finds), and immovable monuments, which usually represent the most known and best visible part of heritage (e.g. state castles, mansions and other state monuments, ecclesiastical and religious buildings, selected urban buildings or rural architecture and other buildings in the landscape, inclusive of technical monuments). A significant component of immovable cultural heritage are the so-called small buildings, mainly chapels, wayside shrines, but also exterior sculptures, groups of statues and other sculptural works". Ibidem, p. 17.

7 It accentuates the so-called edutainment, that is, a combination of education and entertainment or, in other words, education through entertainment. HAVLŮJOVÁ, Hana, Petr HUDEC and Martina INDROVÁ et al. Památky nás baví 1: Objevujeme kulturní dědictví s předškoláky a žáky 1. stupně základních škol. Metodika tvorby, realizace a hodnocení kvality edukačních programů $v$ oblasti péče o kulturní dědictví pro primární vzdělávání [online]. Praha: Národní památkový ústav, 2015, p. 14 [accessed 2019-12-13]. Available from www: <https://www.npu.cz/publikace/ pamatky-nas-bavi-1.pdf $>$. 
heritage pedagogue. ${ }^{8}$ The main objective of heritage education is to develop a positive relationship of all generations to cultural and historical heritage. In connection with transmission of education content in the context of heritage education, the interpretation of cultural heritage is defined as an art to explain the significance and uniqueness of a place with the aim to promote the idea of its protection, to instigate independent thought and pursue context-related experience, and to reveal deeper context. ${ }^{9}$

\section{Psychological preconditions and specifics for the formation and development of a relationship to cultural and historical heritage}

The umbrella aspect of considerations about individual or group preferences in selection of leisure activities from the sphere of cultural and memory institutions is the true reason for the participation of audience in culture and art. According to an American research conducted by Chris Walker, Stephanie ScottMelnyk and Kathy Sherwood

8 Cf. the term educator in culture, which in the Czech legislation (Czech National System of Occupations) since 2018 covers the educational activity of workers in cultural and memory institutions, particularly museums, heritage buildings and libraries. Unlike this cumulative definition, a pedagogical worker, referred to as heritage pedagogue, is defined as a person who is able to recognize the educational potential of a particular heritage building, site or proces and to mediate it to the public, following the educational goals and procedures appropriate to the relevant audience; heritage pedagogue is a guide to those who learn about the environment of cultural heritage. HAVLŮJOVÁ, Hana, Petr HUDEC and Martina INDROVÁ et al. Památky nás baví 1: Objevujeme kulturní dědictví s předškoláky a žáky 1. stupně základních škol. Metodika tvorby, realizace a hodnocení kvality edukačních programů $v$ oblasti péče o kulturní dědictví pro primární vzdělávání [online]. Praha: Národní památkovŷ ústav, 2015, p. 17 [accessed 2019-12-13]. Available from www: <https://www.npu.cz/publikace/ pamatky-nas-bavi-1.pdf $>$.

9 Methodically seen, the interpretation of cultural heritage is based on pedagogical constructivism and in the Anglo-Saxon area it is mainly connected with the development of environmental education and interpretation of archaeological heritage. Ibidem, pp. 15-16.
(2002), the most important reasons stated by the respondents were the following ones: spending time with friends or family, accompanying a family member or friend, supporting with the presence an organisation or an event important for one's own community, gaining unusual art experience. ${ }^{10}$

Cultural competence of visitors is characterised as the ability to perceive and enjoy a cultural product. It takes into consideration the perceptive and cognitive skills of individual visitors and personal choice of the way of spending the leisure time and relaxing. The key role is played by the visitor's motivation. ${ }^{11}$ The perceptive skills of particular visitors and their cultural competences, just as their motivations or, on the contrary, hindrances of visiting a museum, exhibit striking individual differences. The success of a museum institution, apart from the education and relaxation level of visiting the museum, also consists in the type and quality of conveniences and other services offered to visitors. ${ }^{12}$ The act of visiting museums and its effects are also notably influenced by the physical and sensory accessibility of the museum, information ability, price, time demands, perception of the institution's image and offer, ${ }^{13}$ as well as by the opportunity to apply one's own thought, employ emotions, develop social contacts and enjoy the possibility to have some rest and refreshment. ${ }^{14}$ Each

10 KESNER, Ladislav. Marketing a management muzeí a památek. Praha: Grada, 2005, p. 156.

11 Ibidem, pp. 102-115.

12 AMBROSE, Timothy and Crispin PAINE. Museum Basics. London: Routledge, 1995, pp. 56-58; cf. POTTER, Mary Grace. The Care of the Museum Visitor. In Public View: the ICOM Handbook of Museum Public Relations. Paris: ICOM, 1986, pp. 35-39.

13 KESNER, Ladislav. Marketing a management muzeí a památek. Praha: Grada, 2005, pp. 102-115

14 HOOPER-GREENHILL, Eilean. Museums and their Visitors. 2nd Ed. London, New York: Routledge, 1996, p. 96. visitor in each museum should feel welcome. This feeling is then strengthened by cosiness and cleanness, display of interest for visitors and by a comfortable interior design achieved through furniture, decorations, colours, fragrances and sounds. ${ }^{15}$

\subsection{Experience in cultural education}

The expected experience in cultural institutions is tightly related to the personality of every single visitor. Determinant factors are the visitor's cultural competence and the external and internal conditions of visiting a museum (e.g. motivation, personal preferences and their transformations during the lifetime, expected benefits) as well as the socio-cultural context. Cultural heritage is the topic of debates between representatives of various countries, regions and spheres of activities with different level of involvement of individuals - individualised perception of some cultural values and key issues and aspects, which can comprise nationality, sex, ethnicity, social rank, confession, poverty, civilisation diseases, professional qualification and age. As regards the emotional effect, we must therefore take into consideration that some individuals may perceive their museum experience as a trigger of negative feelings, such as the feeling of detachment, severance or ignorance, or they may feel the urge to find oneself. ${ }^{16}$

Museum visitors, exactly like the museums themselves, create certain typology of their own personal profiles. The extent and quality of

15 Cf. e.g. SCHUSTER, Martin and Hildegard AMELN-HAFFKE (eds.). Museums-Psychologie: Erleben im Kunstmuseum. Göttingen: Hogrefe Verlag, 2006, pp. 151-168, 261-277, 303-314.

16 HOWARD, Peter. Heritage: Management, Interpretation, Identity. London, New York: Continuum, 2003. 
their experiences and the personal benefits of visiting museums are tightly related to preferences for particular types of museums according to their profile and the relevant expected experiences. Linda Wasmer Andrews, with reference to a research conducted by the Smithsonian Institution, characterizes four types of experiences, which the museum visitor perceives as the most selfsatisfying ones:

1) object experiences - enabling to observe unique, valuable or aesthetically high-valued objects,

\section{2) cognitive experiences -}

influencing the acquisition of knowledge or deepening of understanding,

\section{3) introspective experiences -}

influencing the imagination in time and space or understanding the meaning of events,

4) social experiences - influencing the interaction with others or observation of the learning process in children.

The majority of museums offer a combination of one part or of all of these four types, where the object experience is mostly dominant in art museums, cognitive experience in technical museums, introspective experience in historical museums and social experience in children's museums. ${ }^{17}$

Several authors pay an increased attention to the typology of experiences; for example, Neil and Philip Kotler specify the recreational, social, educational, aesthetical (visual and sensory), celebrative and enchanting museum

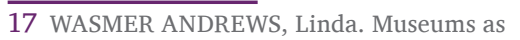
Healing Places: Musings on the mind-body health benefits of museums. Psychology Today [online]. 22. 12. 2010 [accessed 2019-10-19]. Available from www: < https://www.psychologytoday. com/blog/minding-the-body/201012/museumshealing-places $>$. experiences. These are described by John Falk and Lynn Dierking as a result of interaction between three contexts - personal (visitor's), social (in interaction with the surrounding world) and physical (museum).$^{18}$ However, Ladislav Kesner at the same time warns about an excessive use of the Czech term prožitek (in fact enjoyment, not mere experience) in relation to museums (this might be connected with possible inaccurate translation of texts from the English language where the word experience has two Czech equivalents with slightly different meaning zážitek/prožitek and zkušenost, comm. LJ) in the context of various interactive, adrenaline, authentic and participative activities at the expense of "normal" regarding and viewing. This generates a dangerous contradiction between "active experience" and simple "regarding", i.e. "perception of static objects or the experience of space in a monument."19

\subsection{Attention and regeneration of mental strength while visiting a cultural institution}

The premises of a museum (or some other cultural and memory institution) represent a constant emotional, intellectual and visually stimulating environment of a particular institution. It encompasses three mutually interlinked elements, namely atmosphere - dynamics experience, ${ }^{20}$ which are related both to the building itself, its interior spaces and exhibition rooms, and to the overall climate of the institution, i.e. how it emotionally impacts the visitors and how they feel inside.

The importance of natural environment and authentic

\footnotetext{
18 KESNER, Ladislav. Marketing a management muzeí a památek. Praha: Grada, 2005, p. 117.

19 Ibidem, pp. 116-117.

20 AMBROSE, Timothy and Crispin PAINE. Museum Basics. London: Routledge, 1995, pp. 220-222.
}

places - in contrast to impressive monumental buildings overflowing with numbers of exhibits and symbols with many educational meanings (causing the risk of overstimulation of visitors by an excessive amount of stimuli comm. LJ) - is accentuated in the attention regeneration theory by the psychologists Rachel and Stephen Kaplan (1980s). According to this theory, many usual daily activities require a directed (voluntary) attention, which is determined by a great deal of cognitive effort. Excessive directed attention may lead to the so-called directed attention fatigue (mental exhaustion), which is characterised by the inability to concentrate, irritability, impulsiveness, frustration, fatigue and lower performance efficiency in fulfilling the duties. Regeneration of this ability demands the activation of automatic attention. ${ }^{21}$ The Kaplan theory, verified by research and confirming the effective impact of spending time in nature (natural environment contains fascinating objects that automatically captivate human attention and help to mitigate the negative effect of directed attention fatigue), is characterised by four important attributes. Australian researcher Jan Packer applied them to the potential of museum environment and modified them as follows:

\section{1) fascination or involuntary} attention focused on all interesting things around us,

2) taking a walk outdoors or visiting a museum as a place of retreat from daily routine and an opportunity to let oneself be absorbed by a new world,

\footnotetext{
21 WASMER ANDREWS, Linda. Museums as Healing Places: Musings on the mind-body health benefits of museums. Psychology Today [online]. 22. 12. 2010 [accessed 2019-10-19]. Available from www: <https://www.psychologytoday. com/blog/minding-the-body/201012/museumshealing-places $>$.
} 
3) occupation of attention or detection of many stimuli to be processed or to be kept in mind,

4) consonance with the environment, or examination of exhibits which satisfy our personal interests and needs. ${ }^{22}$

It turns out that the peace of mind achieved during leisure "walks" (no matter if by enjoying art, by admiring science or by immersing oneself in remote times and places) may help individuals feel relief and "take a breath again". In Packer's research (2008), the visitors who were asked to name the benefits of museum experiences leading to regeneration of attention have mentioned e.g. relaxedness, wellbeing, serenity and contemplation. ${ }^{23}$ Particularly beneficial in this regard proved to be the interactive, stimulating, didactic and funny presentations as well as the necessity to offer enough rest areas for possible relaxation, seating and refreshment. ${ }^{24}$ On the other hand, there is an undesirable museum fatigue syndrome (colloquially called "museum feet"), which is a specific type of exhaustion of

22 WASMER ANDREWS, Linda. Museums as Healing Places: Musings on the mind-body health benefits of museums. Psychology Today [online]. 22. 12. 2010 [accessed 2019-10-19]. Available from www: <https://www.psychologytoday. com/blog/minding-the-body/201012/museumshealing-places >; cf. PAVLÍKOVÁ, Václava. Psychologické výzkumy vlivu kontaktu s př́rodou na duševní zdraví člověka [online]. Brno:

Masarykova univerzita, Fakulta sociálních studií, Katedra environmentálních studií, 2015, pp. 22-23 [accessed 2019-10-19]. Master's thesis. Supervisor PhDr. Jan Krajhanzl, Ph.D. Available from www: <http://is.muni.cz/th/416461/ fss m/DIPLOMOVA PRACE - VACLAVA PAVLIKOVA.pdf $>$.

23 WASMER ANDREWS, Linda. Museums as Healing Places: Musings on the mind-body health benefits of museums. Psychology Today [online]. 22. 12. 2010 [accessed 2019-10-19]. Available from www: <https://www.psychologytoday. com/blog/minding-the-body/201012/museumshealing-places $>$.

24 AMBrose, Timothy and Crispin PAINE. Museum Basics. London: Routledge, 1995,

pp. 220-222; cf. KAISER, Brigitte. Inszenierung und Erlebnis in kulturhistorischen Ausstellungen: Museale Kommunikation in kunstpädagogischer Perspektive. Bielefeld: transcript Verlag, 2006, pp. 97-172. museum visitors from a prolonged standing or slow walking through a museum without any possibility of taking a rest. It can be caused and further worsened mainly by learning in standing position, which is typical of museums and other cultural and memory institutions, by disorientation in exhibition rooms and exhibits, use of the eyesight without any longer connection to the other senses like touch, hearing and smell, long observation of different but very similarly looking objects, lack of contrasts, monotonous environment, crowds of people, inappropriate temperature. ${ }^{25}$

\section{A good overall concept of} institution premises and their equipment, which is further strengthened by a systematic and didactically and psychologically well-considered educational effect, enhances the understanding of how the participation in cultural and creative activities can produce an evident and measurable impact on physical health and well-being of visitors, or how a regular cultural consumption (e.g. visiting a museum, gallery or concert) "stimulates the existence of humans and brings them balance, representing a value which prolongs their life". Although many questions still remain unanswered, this topic, just as intentional promotion of visitor's emotional experience, represents a huge potential for museums. ${ }^{26}$

\subsection{Emotions in museum education}

The cognitive, sensorimotor and social learning are pursued with

\footnotetext{
25 AMBROSE, Timothy and Crispin PAINE. Museum Basics. London: Routledge, 1995, p. 223. 26 DODD, Jocelyn and Ceri JONES. Mind, body, spirit: How museums impact health and wellbeing [online]. Leicester: University of Leicester, School of Museum Studies, Research Centre for Museums and Galleries, June 2014, p. 7 [accessed 201910-19]. Available from www: <https://www2. le.ac.uk/departments/museumstudies/rcmg/ publications/mind-body-spirit-report $>$.
}

increasing intensity, mainly in museum education. Apart from that, an intensified professional discussion is also held on the necessity of cultural institutions to develop a directed working with emotions and to support the emotional impact on visitors, which influences the quality of visitor's cultural experience. Such an example might be the 2019 Connected Audience conference in Berlin, which was dealing with this problem. ${ }^{27}$ The main thematic sessions within the conference were based on its subtitle The Role of Emotions in Museum and Cultural Experiences. They were focused on:

1) building respect, magic and empathy in museums and in cultural experiences,

2) the role of emotions in visitor engagement and satisfaction,

3) emotion as the driving force in decision making and its potential for creation of the programme offer and marketing of institutions. ${ }^{28}$

We understand emotions as the fundamental aspects of human behaviour, which influence learning and the development of memories. They are determined by social factors and may help establish connections which are very important for cultural institutions and their activities in the field of development of audience. Museum experiences in the past were concentrated too much on the transmission of knowledge, based on intellect and logic. However,

\footnotetext{
27 DROBNÝ, Tomáš and Pavla VYKOUPILOVÁ. Connected Audience 2019 Berlin, konference, která nabídla emoce v berlínských muzeích. Museologica Brunensia, 2019, vol. 8, no. 2, pp. 64-65.

28 For more details, see Connected Audience Conference 2019: The Role of Emotions in Museum and Cultural Experiences. In KulturAgenda. Institut for Museums, Cultural Enterprises and Audiences [online]. [accessed 2019-12-13]. Available from www: <https:// www.kulturagenda.at/connected-audienceconference-2019/>
} 
researches have shown that emotions are the key factor for the engagement of visitors and that the impact of emotional effect distinctly influences the experiences and effects of the effort to satisfy individual needs of visitors and to establish efficient connections to local communities. For museums and other cultural institutions, the working with emotions represents a challenge in exhibition making and development of their educational activity and particular programmes and activities targeted at audience.

From the perspective of museum didactics, the creation of educational programmes and fulfilment of the educational mission of various presentation forms and museum work with visitors involve experiential education. It is a didactic approach based on working with emotions and on acquisition of knowledge through visitor's own experience, often in combination with object learning, which is a characteristic feature of museum institutions. In order to strengthen the effectiveness of museum education, it is suitable to deliberately promote the so-called optimal experience (flow) - the setting of a positive state of mind, full of concentration, in which the museum activities are conducted by participants very successfully, they are enjoyed by the visitors and are accompanied by the feeling of spontaneous delight and captivation, where everybody forgets the time and overcomes the boundaries of self. ${ }^{29}$

29 For more details, see JAGOŠOVÁ, Lucie. Psychologické aspekty muzejní edukace. (Studijní text ke kurzu Múzejná pedagogika). Manuscript, 2017, 13 p. Internal materials for participants in the Museum Pedagogy course in the Slovak National Museum in Bratislava; JAGOŠOVÁ, Lucie. Psychologické aspekty muzejní edukace. In Metodické centrum muzejní pedagogiky [online]. Brno: Moravské zemské muzeum, Metodické centrum muzejní pedagogiky, 2016 [accessed 2019-12-13]. Available from www: <http://www. mcmp.cz/fileadmin/user_upload/vzdelavani/ MCMP_2015_text_Psychologicke_aspekty_muzejni_ edukace_FINAL.pdf $>$. Learning text for the Basics

\section{Conclusions}

In recent years, apart from the educational role of museums and other cultural institutions also some other aspects have been discussed with increasing intensity - cultural competences of visitors and their motivation to visit a cultural institution, inner processes which are taking place during education and are based on, and retrospectively influence, the visitor's personality from a psychological perspective. These processes, besides the didactic quality of education, also incorporate the maintaining of attention and deliberate working with the emotions of visitors, and promotion of "well-being". Cultural education (museum education, heritage education), apart from the requirement for cognitive or social development, thus gradually draws attention to musings on other levels of qualitative benefits for the visitors, which have the potential to positively influence the quality of everyday life of individuals. Institutions are able to achieve this undoubtedly ambitious objective by promoting the development of affective goals and education tools and by the effort to transform the institution into an environment which stimulates, guides and helps regenerate the mental strength of visitors. The current vision of cultural and memory institutions, which is so far noticeable in theoretical works and in the practice of museum institutions, is to exert a balanced effect on intellect, socio-cultural and value development and emotions, to promote motivation, interest and attention of visitors and to offer space for contemplation and recreation of strength in an adequately stimulating environment.

of Museum Pedagogy course; JAGOŠOVÁ, Lucie, Vladimír JŮVA and Lenka MRÁZOVÁ. Muzejní pedagogika. Metodologické a didaktické aspekty muzejní edukace. Brno: Paido, 2010, pp. 216-217.

\section{REFERENCES:}

AMBROSE, Timothy and Crispin PAINE. Museum Basics. London: Routledge, 1995. ISBN 0-415-05770-1.

Connected Audience Conference 2019: The Role of Emotions in Museum and Cultural Experiences. In KulturAgenda. Institut for Museums, Cultural Enterprises and Audiences [online]. [accessed 2019-12-13]. Available from www: <https://www.kulturagenda. at/connected-audience-conference-2019/>.

DODD, Jocelyn and Ceri JONES. Mind, body, spirit: How museums impact health and wellbeing [online]. Leicester: University of Leicester, School of Museum Studies, Research Centre for Museums and Galleries, June 2014 [accessed 2019-10-19]. Available from www: < https://www2. le.ac.uk/departments/museumstudies/ rcmg/publications/mind-body-spiritreport >. ISBN 978-1-898489-49-8.

DROBNÝ, Tomáš and Pavla VYKOUPILOVÁ. Connected Audience 2019 Berlin, konference, která nabídla emoce v berlínských muzeích. Museologica Brunensia, 2019, vol. 8, no. 2, pp. 64-65. ISSN 1805-4722. https://doi.org/10.5817/MuB2019-2-9

ELLARD, Colin. What Happens When You Take a Psychologist to a Museum?: New methods can help us understand how we act and feel in galleries and museums. Psychology Today [online]. 26. 2. 2013 [accessed 2019-12-13]. Available from www: <https://www. psychologytoday.com/blog/mindwandering/201302/what-happens-whenyou-take-psychologist-museum $>$.

Effects of creative museum outreach sessions on measures of confidence, sociability and well-being for mental health and addiction recovery service-users. Arts \& Health: An International Journal for Research, Policy and Practice [online]. 2015, vol. 7, no. 3, pp. 231-246 [accessed 2019-12-13]. Available from www: < http://www.tandfonline.com/doi/pdf/ 10.1080/17533015.2015.1061570>. https://doi.org/10.1080/17533015.2015.1061570

FALK, John H. and Lynn D. DIERKING. Learning from Museums: Visitor Experiences and the Making of Meaning. Oxford: AltaMira Press, 2000. ISBN 0-7425-0295-3.

FOLGA-JANUSZEWSKA, Dorota. Might the Museology be a part of Neurosciences? 
Museologica Brunensia, 2016, vol. 5, no. 1 , pp. 5-14. ISSN 1805-4722. https://doi.org/10.5817/MuB2016-1-1 HAVLŮJOVÁ, Hana, Petr HUDEC and Martina INDROVÁ et al. Památky nás baví 1: Objevujeme kulturní dědictví s předškoláky a žáky 1. stupně základních škol. Metodika tvorby, realizace a hodnocení kvality edukačních programů $v$ oblasti péče o kulturní dědictví pro primární vzdělávání [online]. Praha: Národní památkový ústav, 2015 [accessed 2019-12-13]. Available from www: <https://www.npu.cz/ publikace/pamatky-nas-bavi-1.pdf $>$. ISBN 978-80-905631-6-2.

HOOPER-GREENHILL, Eilean. Museums and their Visitors. 2nd Ed. London, New York: Routledge, 1996. ISBN 0-415-06857-6.

HOWARD, Peter. Heritage: Management, Interpretation, Identity. London, New York: Continuum, 2003. ISBN 0-8264-5898-X.

JAGOŠOVÁ, Lucie. Psychologické aspekty muzejní edukace. (Studijní text ke kurzu Múzejná pedagogika). Manuscript, 2017, $13 \mathrm{p}$. Internal materials for participants in the Museum Pedagogy course in the Slovak National Museum in Bratislava. JAGOŠOVÁ, Lucie. Psychologické aspekty muzejní edukace. In Metodické centrum muzejní pedagogiky [online]. Brno: Moravské zemské muzeum, Metodické centrum muzejní pedagogiky, 2016 [accessed 2019-12-13]. Available from www: $<$ http://www.mcmp.cz/fileadmin/ user_upload/vzdelavani/MCMP_2015_text_ Psychologicke_aspekty_muzejni_edukace_ FINAL.pdf > . Learning text for the Basics of Museum Pedagogy course.

JAGOŠOVÁ, Lucie, Vladimír JŮVA and Lenka MRÁZOVÁ. Muzejní pedagogika: Metodologické a didaktické aspekty muzejní edukace. Brno: Paido, 2010. ISBN 978-80-7315-207-9.

JANES, Robert R. Museums in a Troubled World. Renewal, Irrelevance or Collapse? London, New York: Routledge, 2009. ISBN 0-415-46301-7. https://doi.org/10.4324/9780203877456

KAISER, Brigitte. Inszenierung und Erlebnis in kulturhistorischen Ausstellungen: Museale Kommunikation in kunstpädagogischer Perspektive. Bielefeld: transcript Verlag, 2006. ISBN 3-89942-452-2.

https://doi.org/10.14361/9783839404522

KESNER, Ladislav. Marketing a management muzeí a památek. Praha: Grada, 2005. ISBN 80-247-1104-4.

MRÁZOVÁ, Lenka. Poznámky k pojmu motivace $\mathrm{v}$ práci muzejního pedagoga. Museologica Brunensia, 2013, no. 3, pp. 26-31. ISSN 2464-5362.

Museology: Back to Basics / Muséologie: revisiter nos fondamentaux / Museologia: retorno a las bases. Morlanwelz: Musée royal de Mariemont, 2009. ISBN 978-2-930469-26-3. ICOFOM Study Series, Issue 38. Working Papers.

PAVLÍKOVÁ, Václava. Psychologické výzkumy vlivu kontaktu s prírodou na duševní zdraví člověka [online]. Brno: Masarykova univerzita, Fakulta sociálních studií, Katedra environmentálních studií, 2015 [accessed 2019-10-19]. Master's thesis. Supervisor PhDr. Jan Krajhanzl, Ph.D. Available from www: <http://is.muni.cz/ th/416461/fss_m/DIPLOMOVA_PRACE_VACLAVA_PAVLIKOVA.pdf $>$.

POTTER, Mary Grace. The Care of the Museum Visitor. In Public View: the ICOM Handbook of Museum Public Relations. Paris: ICOM, 1986, pp. 35-39. ISBN 92-9012-107-6.

SCHOUTEN, Frans. Visitor perception: the right approach. In Reinwardt Studies in Museology: Exhibition Design as an Educational Tool. Leiden: Reinwardt Academy, [1983], pp. 37-46.

SCHUSTER, Martin and Hildegard AMELN-HAFFKE (eds.). MuseumsPsychologie: Erleben im Kunstmuseum. Göttingen: Hogrefe Verlag, 2006. ISBN 3-8017-1682-1.

WASMER ANDREWS, Linda. Museums as Healing Places: Musings on the mind-body health benefits of museums. Psychology Today [online]. 22. 12. 2010 [accessed 2019-10-19]. Available from www: <https://www. psychologytoday.com/blog/minding-thebody/201012/museums-healing-places $>$.

Základy muzejní pedagogiky: Studijní texty. Brno: Moravské zemské muzeum, 2014. ISBN 978-80-7028-441-4.

\section{LUCIE JAGOŠOVÁ}

Department of Archaeology and Museology, Faculty of Arts, Masaryk University, Brno, Czech Republic; Department of Ethnology and Museology, Faculty of Arts, Comenius University in Bratislava, Slovak Republic

jagosova@phil.muni.cz

Lucie Jagošová is head of the museological section of the Department of Archaeology and Museology at the Faculty of Arts of Masaryk University in Brno. At the same time, she is doctoral student in museology at the Comenius University in Bratislava. She teaches and publishes on the topics of museology, museum pedagogy and psychology. She also is executive editor of the journal Museologica Brunensia. She is lecturer in accredited education courses for museum pedagogues in the Czech Republic and in Slovakia. Currently she is chairwoman in the Committee for Public Relations and Museum Pedagogy of the Czech Association of Museums and Galleries.

Lucie Jagošová vede oddělení muzeologie na Ústavu archeologie a muzeologie Filozofické fakulty Masarykovy univerzity v Brně. Na Univerzitě Komenského v Bratislavě studuje muzeologii v doktorském stupni. Přednáší a publikuje $\mathrm{k}$ tématům z muzeologie, muzejní pedagogiky a psychologie. Je výkonnou redaktorkou časopisu Museologica Brunensia. Přednáší také $\mathrm{v}$ akreditovaných kurzech pro vzdělávání muzejních pedagogů v České republice a na Slovensku. V současnosti předsedá Komisi pro práci s veřejností a muzejní pedagogiku při Asociaci muzeí a galerii České republiky. 